\title{
Changes in Levels of Back Pain in Third Trimester of Pregnant Women Who Do Yoga Exercises
}

\author{
Susi Irianti ${ }^{1^{*}}$, Sunah Nurjanah ${ }^{2}$ \\ ${ }^{I}$ Midwifery professional Education study program, Faculty Of Health Sciences, Universitas Faletehan \\ ${ }^{2}$ Midwifery Diploma Study Program, Faculty Of Health Sciences, Universitas Faletehan \\ *iriantisusi85@yahoo.co.id
}

\begin{abstract}
Back pain is a common disorder in pregnancy, pregnant women may have had back pain before. To deal with back pain, you can do yoga exercises which are useful for forming an upright posture, purifying the central nerves found in the spine. This research was an experimental one group pretest posttest design with a questionnaire measuring instrument and a pain scale measurement to collect the data. The sample of this study used accidental sampling with a sample of 16 trimester III pregnant women at Masita Clinic, Cilegon City. The results of this study showed that the pain scale in the pretest was on a scale of 1 (slight pain) as many as 11 pregnant women $(68.75 \%)$ and the pain scale in the postest for some of the respondents were on a pain scale of 0 (no pain) as many as 8 pregnant women $(50 \%)$. In terms of maternal characteristics, all respondents were aged 20-35 years (100\%), most of the college as latest education were 11 pregnant women $(68.75 \%)$ and working as housewives were 6 pregnant women (37.5\%). Based on the results of the study, it can be concluded that there was a decrease in the level of back pain in third trimester pregnant women who experience back pain after doing yoga. At the pretest, most of the 11 respondents who experienced a little pain became not experiencing pain by 8 respondents in the posttest.
\end{abstract}

Keywords: Third Trimester Pregnancy, Back Pain, Yoga 


\section{STRADA Jurnal Ilmiah Kesehatan}

DOI: $10.30994 /$ sjik.v9i2.501

ISSN: 2252-3847 (print); 2614-350X (online)

Vol.9 No.2 November 2020 Page. 1581-1587

\section{BACKGROUND}

Pregnancy is a natural process, the duration of 280 days (40 weeks or 9 months 7 days) is calculated from the first day of the last menstruation. There are physical and psychological changes in women during the pregnancy process that cause discomfort. Psychological changes during pregnancy make mothers more sensitive so that thoughts arise about the past and the future. This can lead to fear, threat, and even stress that can cause other pregnancy discomforts such as insomnia, hurtburn, and even depression. Physical changes include discomfort and pain, especially those that occur in the third trimester of pregnancy. The growth in fetal weight drastically pushes the diaphragm to press the lungs causing the mother to feel short of breath and tired quickly. The enlargement of the abdomen makes the body burden excessively pushes the spine which makes the posture lordosis, as a result the mother is at risk of low back pain, leg cramps, and varicose veins (Cunningham 2014; Curtis 2000; Pratignyo Tio 2014)

Back pain during pregnancy usually occurs due to stretching of the bones, especially in the waist area which corresponds to increasing gestational age. Back pain often occurs because the point and balance of the mother has changed from its original condition, so it requires effective and safe treatment for pregnant women. Efforts to deal with back pain complaints are usually pharmacological and non-pharmacological therapies. Nonpharmacological therapy is considered more effective and safer for pregnant women. One way is to do prenatal yoga. (Mediarti Devi, Sulaiman, Rosnani 2019; Shindu 2011)

The incidence of low back pain in the third trimester of pregnancy is more than $50 \%$ in the United States, Canada, Ice Land, Turkey and Korea. In non-Scandinavian countries such as northern America, Africa, the Middle East, Norway, Hong Kong and Nigeria, the figure is higher, ranging from $21 \%-89.9 \%$. In Indonesia, the incidence of low back pain reaches $60-80 \%$. Based on a preliminary study on 16 pregnant women in the third trimester, there were 6 pregnant women who experienced back pain, 4 pregnant women with a low pain scale and 2 pregnant women with a large scale (Lailiyana, Hamidah 2019)

Yoga is a non-pharmacological method for increasing the strength and flexibility of the mother as well as increasing the ability to become more in tune with her body, because yoga is a body exercise, and other components such as breathing exercises and meditation. Prenatal yoga practice has been shown to be beneficial for pregnant women who experience anxiety, depression, stress, back pain and sleep disorders (Babbar S 2016; Jahdi et al. 2017; Paul Posadzki 2011)

Yoga is a new intervention that combines physical exercises such as stretching, strength and balance using mindfulness, acceptance and self-compassion. Several international studies said that yoga is proven to reduce depression, improve quality of life, reduce labor pain and shorten the length of labor. Yoga can also improve gait, postural stability and flexibility (Holden et al. 2019).

\section{METHODS}

This study was an experimental method with one group pretest-posttest design. Pregnant women were given a pretest questionnaire before being given treatment and a posttest questionnaire after being given treatment. Thus it can be known to be more accurate 


\section{STRADA Jurnal Ilmiah Kesehatan}

DOI: $10.30994 /$ sjik.v9i2.501

ISSN: 2252-3847 (print); 2614-350X (online)

Vol.9 No.2 November 2020 Page. 1581-1587

because it can compare between before being given treatment and after being given treatment. The variables studied included the characteristics of pregnant women (age, education, occupation, parity) and changes in the level of back pain.

The time of the research was carried out from February to March 2020 at Masita Clinic, Cilegon City. The study population was pregnant women in the third trimester, while the sample of the study were 16 trimester pregnant women who experienced lower back pain without comorbidities as many as 16 pregnant women. The sampling technique was nonprobability sampling, namely accidental sampling.

Collecting data in this study used a unidimensional pain assessment scale, namely the Wong Baker Pain Rating Scale, then the data obtained were analyzed using univariate analysis by making pre and posttest frequency distributions.

\section{RESULTS}

1. The results of descriptive analysis of changes in the level of back pain can be seen in table 1.

Table 1. Frequency Distribution of Pre and Post Test Levels of Back Pain

\begin{tabular}{lcccc}
\hline \multicolumn{1}{c}{ Pain Scale } & \multicolumn{2}{c}{ Pre Test } & \multicolumn{2}{c}{ Post Test } \\
\cline { 2 - 5 } & $\mathbf{N}$ & $\%$ & $\mathbf{N}$ & $\%$ \\
\hline 0 (no pain) & 0 & $0 \%$ & 5 & $50 \%$ \\
\hline 1 (slight pain) & 11 & $68,75 \%$ & 2 & $12,5 \%$ \\
\hline 2 (quite pain) & 4 & $25 \%$ & 1 & $6,25 \%$ \\
\hline 3 (pain a lot) & 0 & $0 \%$ & 0 & $0 \%$ \\
\hline 4 (very painful) & 1 & $6,25 \%$ & 0 & $0 \%$ \\
\hline 5 (severe pain) & 0 & $0 \%$ & & $100 \%$ \\
\hline Total & 16 & $100 \%$ & 16 & \\
\hline
\end{tabular}

Based on Table 1, the the scale of back pain before doing yoga exercises in third trimester pregnant women was mostly on scale 1 (slight pain) as many as 11 pregnant women $(68.75 \%)$, and back pain scale after doing yoga exercises in trimester III pregnant women most of them were on a scale of 0 (no pain) as many as 8 pregnant women (50\%).

2. The result of characteristics data can be seen in table 2

Table 2. Distribution Frequency Of Characteristics

\begin{tabular}{ccccc}
\hline No & Variable & Frequent & Percent (\%) \\
\hline 1 & Age & & &
\end{tabular}




\section{STRADA Jurnal Ilmiah Kesehatan}

DOI: $10.30994 /$ sjik.v9i2.501

ISSN: 2252-3847 (print); 2614-350X (online)

Vol.9 No.2 November 2020 Page. 1581-1587

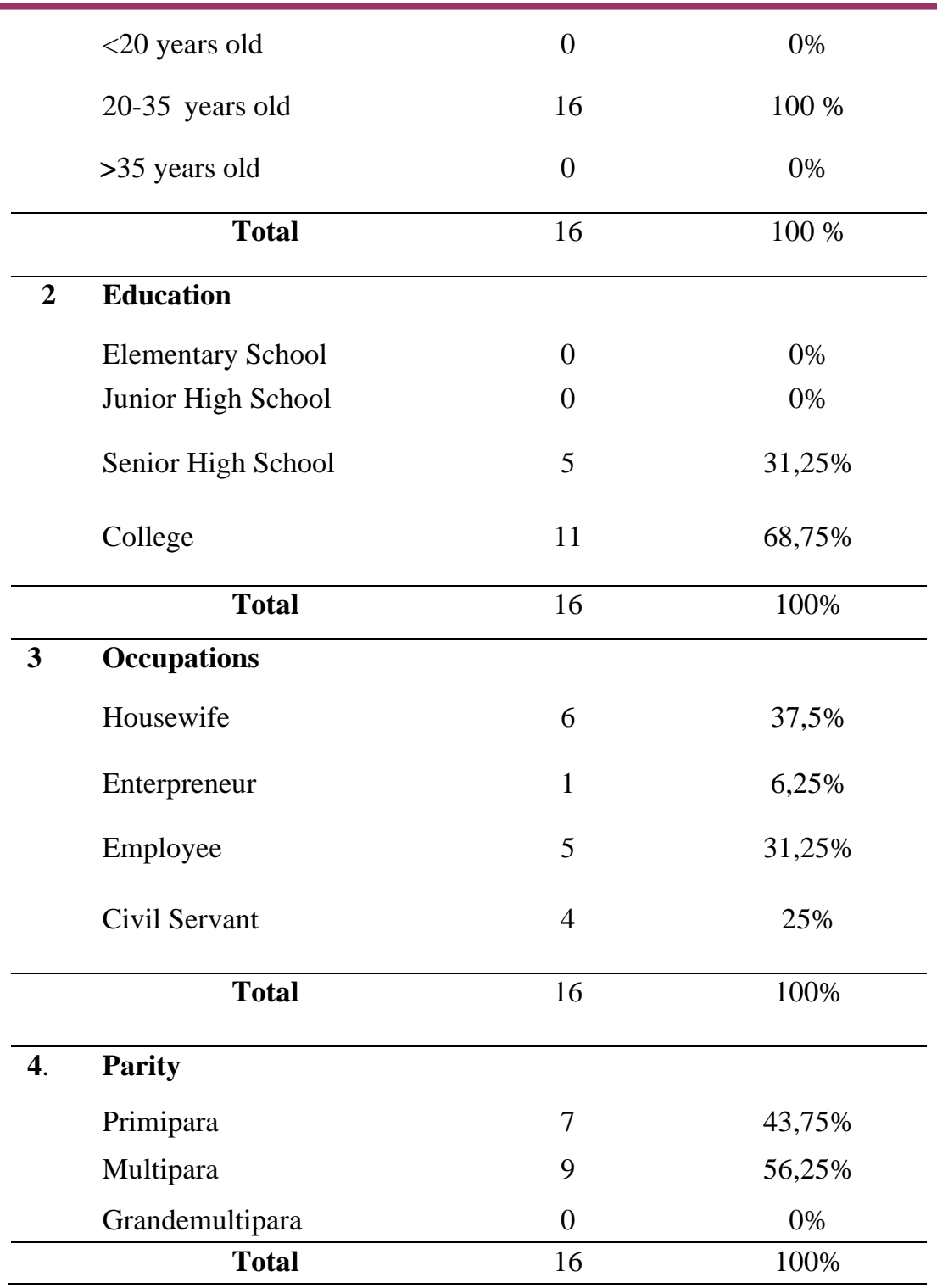

Based on Table 2, respondents aged 20-35 years were 16 respondents (100\%), college educated were 11 respondents $(68.75 \%)$, working as housewives were 6 respondents $(37.5 \%)$, and multiparous parity were 9 respondents $(56.25 \%)$.

\section{DISCUSSION}

Based on the results of the study table 2 shows that back pain before doing yoga exercises in third trimester pregnant women were on a scale of 1 (slight pain) as many as 11 pregnant women $(68.75 \%$ ), and back pain after doing yoga exercises in third trimester pregnant women were back pain with scale 0 (no pain) as many as 8 pregnant women $(50 \%)$.

Back pain is pain that occurs in the lumbosacral area. Back pain is a common disorder, and pregnant women may have a history of back pain in the past. Alternatively, back pain may be felt for the first time in pregnancy. Back pain is so common in pregnancy that it is described as one of the minor disorders in pregnancy. The pregnant woman tilts the stomach so that it adds to the curve of the lower back which causes pain (Varney 2008) 


\section{STRADA Jurnal Ilmiah Kesehatan}

DOI: $10.30994 /$ sjik.v9i2.501

ISSN: 2252-3847 (print); 2614-350X (online)

Vol.9 No.2 November 2020 Page. 1581-1587

Yoga exercise is a practical effort in harmonizing the body, mind, and spirit, where the benefits of yoga are to form a firm posture, and build flexible and strong muscles, reduce the central nerves in the spine, so that yoga is needed and effective for reducing stress and reducing lower back pain, especially for third trimester of pregnant women (Mediarti Devi, Sulaiman, Rosnani 2019; Safarina and Dewi 2018)

In theory, yoga exercises aim to prepare pregnant women physically, mentally, and spiritually for childbirth. By careful preparation, the mother will be more confident and gain the confidence to go through labor smoothly and comfortably (Lebang 2015)

This is in line with the theory, back pain experienced by pregnant women can be caused by excessive activity which can cause fatigue, and improper standing position which can cause back pain. In addition, the mother's stomach, which is getting bigger every day, can also affect the occurrence of back pain. Yoga exercises can reduce back pain in third trimester pregnant women, with a duration of 1-2 hours and must be done according to the SOP so that the maximum benefits can be felt and the mother can feel comfortable going through her pregnancy. The preparations of pregnant women are wearing loose clothes, keeping the stomach from being too full and hungry, practicing in the morning or evening when the stomach is empty. Performed 1-2 hours after eating, for one week done 1-2 times, and drink lots of water.

Table II showed the characteristics of mothers that from 16 respondents, who were aged 20-35 years were 16 respondents (100\%). This age is included in the category of healthy reproductive age which is a safe age for pregnancy and childbirth. Each individual has a different way of interpreting pain. For increasing age, the level of development of adults will experience neurological changes and may experience a decrease in sensory perception of stimuli and an increase in the pain threshold (Resmi, Saputro, and Runjati 2017)

Most of the respondents with college as latest education were 11 respondents (68.75\%). Education will affect the knowledge of pregnant women in getting good information. The higher a person's education, the more quality and experiencing rapid changes in the development of science and technology needed. When the knowledge and information obtained by pregnant women are good, they will be able to overcome the pain complaints they experience (Soekidjo 2012; Wulandari 2019)

Most of the respondents' occupations were 6 respondents (37.5\%) as housewives. Some of the causes of low back pain were activities that are often carried out by housewives, such as, lifting objects, carrying children, but the position is not right. This was in accordance with the results of interviews with some respondents who did not know about changing the right position to avoid back pain. (Resmi et al. 2017)

\section{CONCLUSION}

Based on the results of the study, it can be concluded that there was a decrease in the level of back pain in third trimester pregnant women who experience back pain after doing 


\section{STRADA Jurnal Ilmiah Kesehatan}

DOI: $10.30994 /$ sjik.v9i2.501

ISSN: 2252-3847 (print); 2614-350X (online)

Vol.9 No.2 November 2020 Page. 1581-1587

yoga. At the pretest, most of the 11 respondents who experienced a little pain became not experiencing pain by 8 respondents at the posttest.

It is suggested for the next research that the intervention given is not enough once, but several times to see the extent to which yoga affects lower back pain and add a comparison group so that the results obtained are more varied.

\section{REFERENCES}

Babbar S, Shyken J. 2016. "Yoga In Pregnancy.” Clin Obstet Gynecol 59(3):600-612.

Cunningham. 2014. “Obstetri William.” Jakarta: EGC.

Curtis, Glade B. 2000. Kehamilan Diatas Usia 30. Jakarta: Arcan.

Holden, Selma C., Brad Manor, Junhong Zhou, Chloe Zera, Roger B. Davis, and Gloria Y. Yeh. 2019. "Prenatal Yoga for Back Pain, Balance, and Maternal Wellness: A Randomized, Controlled Pilot Study." Global Advances in Health and Medicine 8:216495611987098. doi: 10.1177/2164956119870984.

Jahdi, Fereshteh, Fatemeh Sheikhan, Hamid Haghani, Bahare Sharifi, Mahshad Khodarahmian, and Nicole Rouhana. 2017. "Yoga during Pregnancy: The Effects on Labor Pain and Delivery Outcomes (A Randomized Controlled Trial)." Complementary Therapies in Clinical Practice. doi: 10.1016/j.ctcp.2016.12.002.

Lailiyana, Hamidah, Wahyuni Sru. 2019. "PERBEDAAN INTENSITAS NYERI PUNGGUNG BAWAH PADA IBU HAMIL TRIMESTER III YANG DILAKUKAN BACK EXERCISE DENGAN DAN TANPA KINESIO TAPPING DI PRAKTIK MANDIRI BIDAN DINCE SAFRINA KOTA PEKANBARU TAHUN 2019.” 69:1920 .

Lebang, E. 2015. Yoga Atasi Backpain. Jakarta: Pustaka Bunda, grup Puspa Swara.

Mediarti Devi, Sulaiman, Rosnani, Jawiah. 2019. "Pengaruh Yoga Kehamilan Terhadap Pengurangan Keluhan Fisik Ibu Hamil Trimester III." Voice of Midwifery 9(1):796805. doi: 10.35906/vom.v9i1.91.

Paul Posadzki, Edzard Ernst. 2011. "Yoga For Low Back Pain: A System Review of Randomized Clinical Trials." Clinical Rheumatology 30(9):1257-62.

Pratignyo Tio. 2014. Yoga Ibu Hamil. Depok: Pustaka Bunda.

Resmi, Dewi Candra, Soeharyo Hadi Saputro, and Runjati. 2017. "Pengaruh Yoga Terhadap Nyeri Punggung Bawah Pada Ibu Hamil Trimester III Di Puskesmas Kalikajar I Kabupaten Wonosobo.” Jurnal Ilmiah Kesehatan 8(1):1-10.

Safarina, Lina, and Shelly Nitmala Dewi. 2018. "Pengaruh Senam Yoga Terhadap Skala Nyeri Low Back Pain (LBP) Pada Dewasa Menengah Di Wilayah Kerja Puskesmas Cimahi Tengah." Sekolah Tinggi Ilmu Kesehatan Jendral Achmad Yani Cimahi 1(1):150-57.

Shindu, Widiastuti. 2011. Yoga Untuk Kehamilan Sehat, Bugar Dan Penuh Makna. 


\section{STRADA Jurnal Ilmiah Kesehatan}

DOI: $10.30994 /$ sjik.v9i2.501

ISSN: 2252-3847 (print); 2614-350X (online)

Vol.9 No.2 November 2020 Page. 1581-1587

Bandung: PT Mizan Pustaka.

Soekidjo, Notoatmodjo. 2012. Pendidikan Dan Perilaku Kesehatan. Jakarta: Rineka Cipta.

Varney, Hellen. 2008. Buku Ajar Asuhan Kebidanan. Jakarta: EGC.

Wulandari, Kiki. 2019. "PENGARUH PRENATAL YOGA TERHADAP NYERI PUNGGUNG PADA IBU HAMIL TRIMESTER III DI STUDIO YOGA BHAVANA SLEMAN DI STUDIO YOGA BHAVANA SLEMAN YOGYAKARTA TAHUN 2019." 